\title{
Building an Agroecological Process towards Agricultural Sustainability: A Case Study from Southern Spain
}

\author{
Manuel González-Rosado (D), Luis Parras-Alcántara *, Jesús Aguilera-Huertas and Beatriz Lozano-García * \\ SUMAS Research Group, Department of Agricultural Chemistry, Soil Science and Microbiology, \\ Faculty of Science, Agri-Food Campus of International Excellence-ceiA3, University of Cordoba, \\ 14071 Cordoba, Spain; mgrosado@uco.es (M.G.-R.); a52aghuj@uco.es (J.A.-H.) \\ * Correspondence: qe1paall@uco.es (L.P.-A.); beatriz.lozano@uco.es (B.L.-G.)
}

check for updates

Citation: González-Rosado, M.;

Parras-Alcántara, L.;

Aguilera-Huertas, J.; Lozano-García, B. Building an Agroecological Process towards Agricultural Sustainability: A Case Study from Southern Spain. Agriculture 2021, 11, 1024. https://doi.org/10.3390/ agriculture11101024

Academic Editors: José

Luis Vicente-Vicente,

Cristina Quintas-Soriano and María D. López-Rodríguez

Received: 17 September 2021

Accepted: 17 October 2021

Published: 19 October 2021

Publisher's Note: MDPI stays neutral with regard to jurisdictional claims in published maps and institutional affiliations.

Copyright: (c) 2021 by the authors. Licensee MDPI, Basel, Switzerland. This article is an open access article distributed under the terms and conditions of the Creative Commons Attribution (CC BY) license (https:// creativecommons.org/licenses/by/ $4.0 /)$.

\begin{abstract}
The urgent need to implement agricultural systems that provide greater sustainability and resilience to the challenges of the climate change process has meant that alternative paradigms for agri-food systems and agriculture have become more relevant in recent times. In this study, we present the building process and consolidation of an agro-ecological project (Extiercol) in a rural area of southern Spain, with a prolonged depopulation process and close connections to nearby urban areas. Through participatory action research, the specific objectives of this study are (1) to describe the agroecological collective process from its creation by a youth association to its establishment as a viable agricultural project; (2) to identify the drivers for the development of this type of transition process towards agricultural sustainability and (3) to analyse urban-rural alliances in the establishment of agroecological projects. Finally, the replicability of this project was assessed, with a special focus on the main barriers to be addressed in order to implement this agricultural system such as difficult to land access or a negative perception of sustainable management by farmers. Through this study we have shown how the connection between the food production area and nearby urban areas can be achieved through an agroecological project.
\end{abstract}

Keywords: sustainable agriculture; rural-urban interaction; agroecology; youth; human-nature connectedness; sustainability transitions; depopulation

\section{Introduction}

Agricultural land comprises 9.1\% of the territory in Spain [1]; in these areas, the transition from organic to conventional agricultural systems took place within a short period of time in the 20th century [2]. In Spain, agricultural workers decreased from $48.5 \%$ of the working population in 1950 to $4 \%$ in 2019 [3], and the rural labour surplus in this process of agricultural system transformation was crucial in the different processes of industrial and tourist development that took place in Spanish and European urban areas. Thus, there was a link between urban growth and expansion; capital accumulation; concentration of the means of production, technologies, innovations and power and the configuration of decapitalised spaces characterised by unemployment, a lack of productive structure, sluggish economic activity and population decline in rural areas [4]. In this context, a territorial relationship of domination and inequality is re-created in which the rural areas are isolated and reduced to a dependent and submissive space for the extraction and production of resources and labour. On the other hand, with this continuous urbanization process, a separation between primary production and consumers is fostered over time [5], with a disconnection from local biological cycles of production and the traditional knowledge related to these production processes.

In rural areas, the agricultural sector and primary agri-food processing activities are key elements in territorial functionality, both in rural development and environmental terms. The fight against depopulation in economically disadvantaged rural areas and the promotion of agri-food activities that are linked to endogenous productive resources 
have long been among the objectives of EU policies [6]. More recently, the introduction of 'greening' measures in the 2013 EU's Common Agricultural Policy (CAP) reform was intended to reduce the environmental effects of agricultural intensification; however, these measures have had limited environmental impacts [7,8]. In European agricultural policies, the productive functionality of agricultural activities seemed to lose weight among these objectives [9] because there is a growing emphasis on the ecosystem services provision. In addition, there has recently been an increase in social awareness and policies towards more sustainable production models that are local or regional in scale and increase food security $[10,11]$. In this paradigm, the link between the supply of local agricultural products and the provision of ecosystem services may be one of the keys to a future shift towards more sustainable regional agroecosystems. In this sense, according to [12] "The agroecosystem is regarded as an epistemological tool for creating an ontology or representation of agriculture based on a system view". For this purpose, the ecosystem services valuation and an equitable value chain with farmers seem to be fundamental aspects.

Limiting global warming to $1.5^{\circ} \mathrm{C}$ above preindustrial levels would require major reductions in greenhouse gas emissions in all economic sectors [13]. At the same time, climate change adaptation and mitigation is one of the greatest challenges facing food production and consumption in the world [14]. Increases in agricultural intensification on a regional and global scale generates serious environmental impacts, such as the reduction of biodiversity [15,16], an increase in greenhouse gas emissions [17], soil degradation [18], as well as a decrease in food security and an increase in the dependence on external resources [19]. Agriculture is one of the main sectors in the emission of greenhouse gases worldwide; in Spain, this sector is responsible for $12 \%$ of total emissions, and they have increased by $8 \%$ since 1990 [20]. However, the agricultural sector has a great potential to contribute to the reduction of emissions and become a key sector for mitigating the effects of climate change [21].Sustainable management practices implementation are not only important to mitigate $\mathrm{CO}_{2}$ emissions and increase the $\mathrm{C}$ sequestration rate in agricultural soils [22] but also to enhance soil organic matter sustainable practices to improve soil quality by increasing soil fertility [23-25], water holding capacity [26,27] resistance to prolonged drought periods [28] and erosion processes [29]. The implementation of sustainable management practices will be of crucial importance to achieve the objectives of the European Green Deal [30] and Horizon Europe Mission on Soil health and Food [31]. However, a real assessment of the sustainability of these kinds of production models must be accompanied by a regionalization of production involving the reduction of the distance travelled by agricultural products from the production area to the consumption area, particularly when designing climate change mitigation strategies [30]. In addition, promoting regional consumption of local agricultural products would have a positive effect on the reduction of the regional carbon footprint since transporting local production produces lower greenhouse gas emissions [32-35].

More agricultural sustainability models are necessary; furthermore, agri-food systems and farming have gained greater importance in recent times in the fight against climate change [36-38]. In this sense, the implementation of agroecological production systems can be an interesting alternative in the search for sustainable production models that can generate employment in rural areas and serve to connect society with the sustainable use of agroecosystems as well as contribute to the Sustainable Development Goals [39-44]. Agroecology aims a holistic view of agricultural systems sustainability, based on the participatory interaction between traditional knowledge and modern science, in order not only to reduce environmental impacts but also to serve the socio-economic needs of farmers and the society [45]. Agroecology promotes the recovery of the logics and practices of local knowledge as a strategy for sustainability [46]. The potential for rural development and population fixation are among the virtues that this approach claims for itself [47]. Agroecological management systems would enhance the territorial functions of rural areas as a space for the ecosystem services provision as well as food quality. 
In the Andalusian region, high urban-rural connectivity, a population spatial distribution with a large number of medium-sized cities that act as the backbone or articulators of the territory [48] and the high agronomic potential mean that sustainable agroecological strategies of local consumption and increased food security are a priori winning strategies. Although there is great potential and a large number of small-scale local agroecological experiences throughout the region, there is no regional strategy to strengthen these elements in order to develop local and sustainable consumption. In this sense, the expansion of monoculture, such as olive cultivation, and the decline of small and medium-sized livestock farms that provide local resources for the organic fertilisation of agricultural soils may be one of the major handicaps in the implementation of this regional strategy.

The purpose of this study was (i) to describe the agroecological collective process from its creation by a youth association to its establishment as a viable agricultural project; (ii) to identify the drivers for the development of this type of transition process towards agricultural sustainability and (iii) to analyse urban-rural alliances in the establishment of agroecological projects. Furthermore, this research aims to identify an agricultural system to promote more efficient types of farming within the regional agri-food system detailing practical aspects, addressing the problems and discussing the impact of the project, in order to improve territorial food security and connect society to the sustainable use of agro-ecosystems.

\section{Materials and Methods}

\subsection{Study Area}

The agroecological study EXperiencias en TIERras COLectivas (Extiercol) is located in the municipality of Cuevas del Becerro (Figure 1). The municipality has an extension of $16 \mathrm{~km}^{2}$ and is in the northwest of the Málaga province (Andalusia, Spain), $80 \mathrm{~km}$ from the Málaga capital. Cuevas del Becerro has traditionally been considered the northern gateway to the Serranía de Ronda. It is an area at the intersection of two regional units, Serranía de Ronda and the Guadalteba-Antequera region, and has physical elements and characteristics common to both areas since it is an extension of the Antequera depression but includes limestone reliefs at medium altitudes characteristic of the eastern area of the Serranía de Ronda These common elements and characteristics extend beyond the physical level and are mixed with the administrative level; on the one hand, the municipality is part of the Comarca del Guadalteba in terms of joint services and strategic European development plans, and on the other hand, it is clearly under the sphere of influence of the municipality of Ronda (18 km away), although it is highly dependent on the economic dynamism of the two most important conurbations in the south of Spain, Costa del Sol (43 km away) and Málaga and its metropolitan area.

The study area is characterised by limestone relief with scarce vegetation and heights above $700 \mathrm{~m}$ above sea level, while in the lower areas there is a predominance of loamy and clayey soils that are crossed by De las Cuevas river and numerous small streams as a consequence of the water sources from the aquifers located in the limestone formations that form the relief of the municipality. The main agricultural land uses are dedicated to extensive rainfed crops such as olive groves, almond and cereal crops, although there are a great number of small recreational gardens around the village. The predominant livestock farming in the region is extensive sheep farms and to a lesser degree goats and horses. On the other hand, agrotourism is not a developed activity in the region although rural tourism is growing with a large number of rural accommodations. Annual rainfall is around $600 \mathrm{~mm}$, the monthly distribution of rainfall is concentrated in the late autumn and winter months, decreasing during the spring and becoming very scarce during the summer season. The annual temperatures are characterised by a large thermal contrast between the summer and winter months with frequent frosts in the cold months. The average annual temperatures are around $14.3^{\circ} \mathrm{C}$, with a minimum of $7.5^{\circ} \mathrm{C}$ in January and maximums of $23^{\circ} \mathrm{C}$ in July on average. 


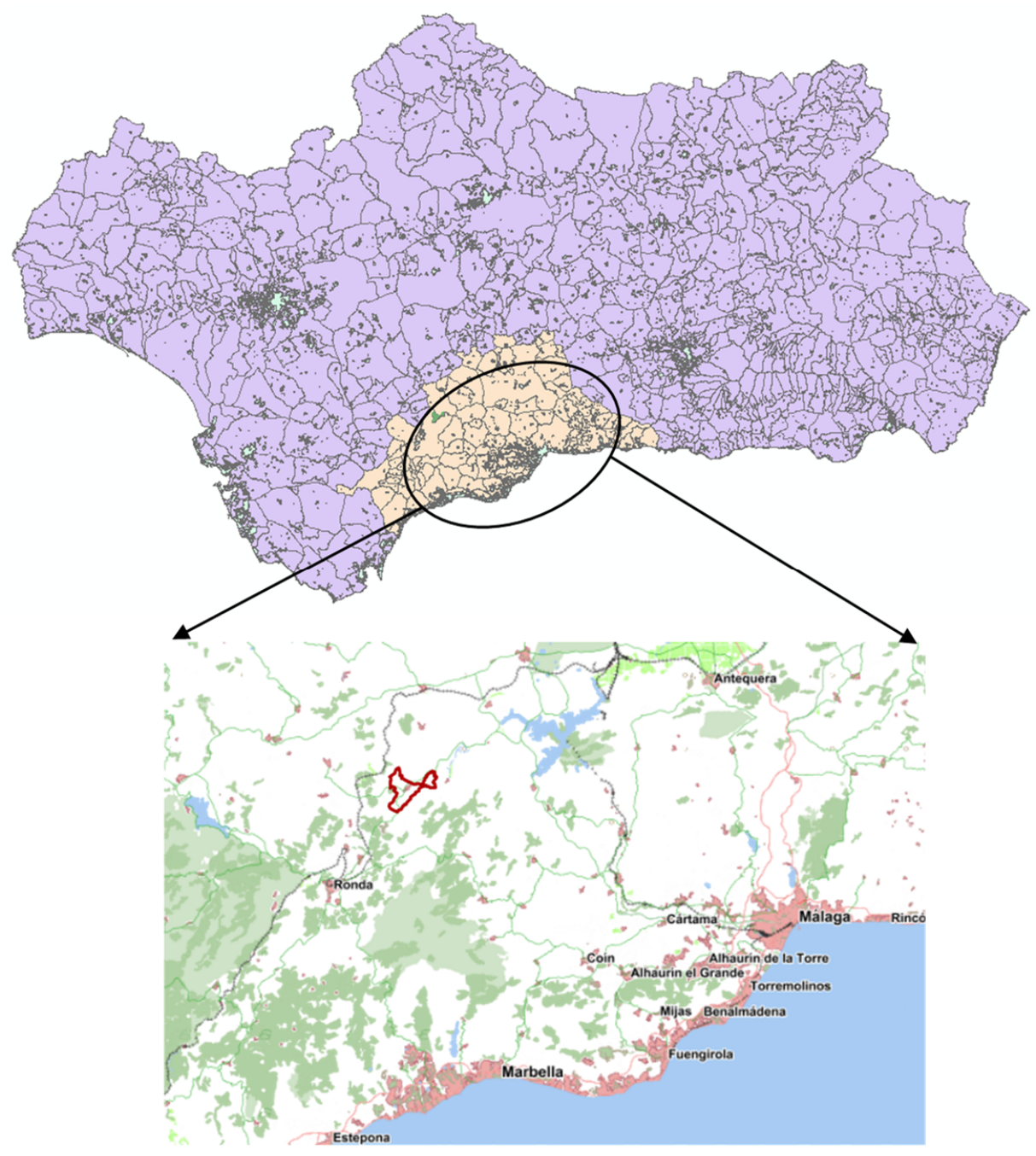

Figure 1. Map of Andalusian region (purple colour) Málaga providence (yellow colour) and Cuevas del Becerro municipality (red outline).

\subsection{Study Area History}

The demographic dynamics of the territory can be a useful indicator of the socioeconomic dynamics and, therefore, of the context and situation in which this project was framed. The municipality had a total population of 1597 in 2020, a consequence of a continuously declining population in the last 80 years.

In order to understand the local population evolution (Figure 2), it is necessary to consider the economic dynamics of Cuevas del Becerro. This economic dynamic is characterised by its dependence, during most of the 20th century, exclusively on agricultural activity. In the municipality, this agricultural activity has not been characterised by its dynamism and diversification; rather, it has remained dedicated to a little diversified and constant production, dedicated especially to extensive cereal crops (mainly wheat) in rotation with anise or chickpea, which, in recent decades, has been displaced as the main crop by the olive tree. 


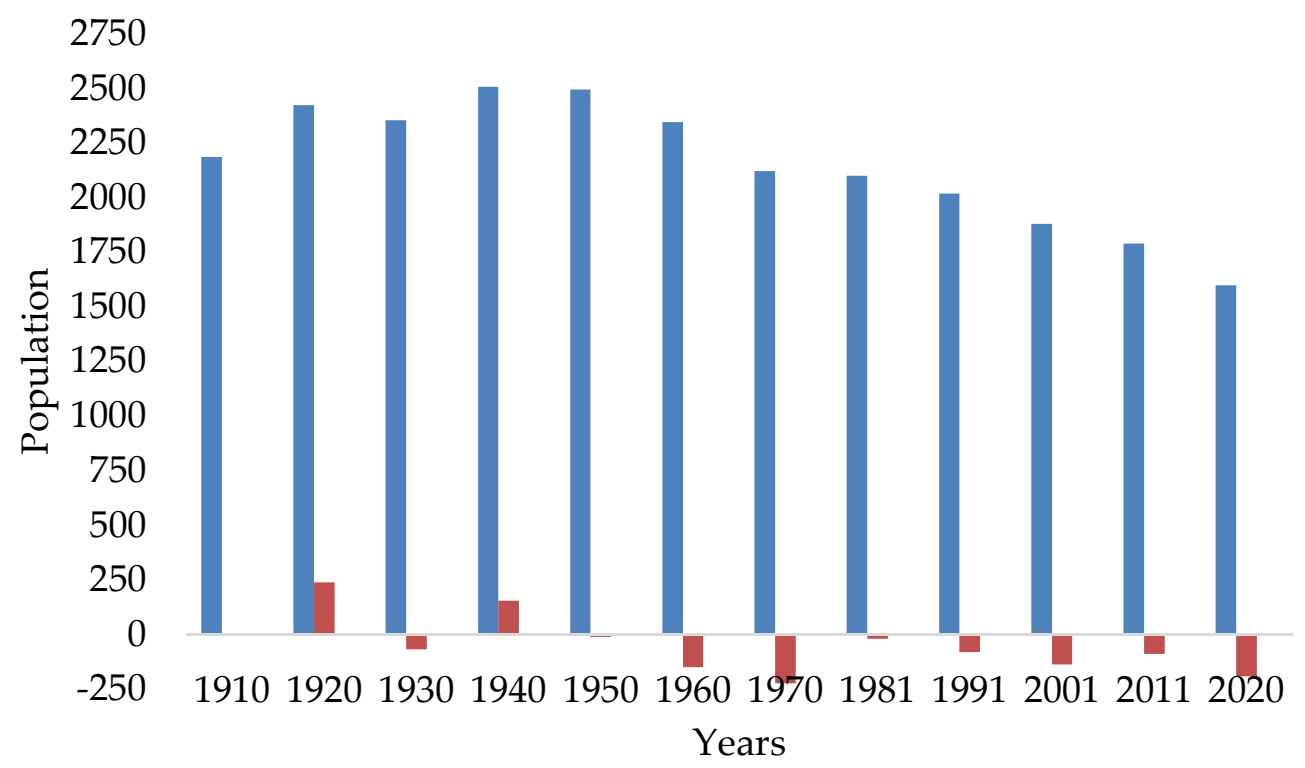

Figure 2. Total population (blue bars) and variation in total population in the given period (red bars) in Cuevas del Becerro (1910-2020).

Agricultural activity employed, and still employs, the vast majority of the municipality's population, most of them day labourers who only work during the harvesting season and therefore experience a high level of seasonal unemployment, a situation that continues to persist to the present day. Given the impossibility of employing the entire working population in agriculture and the poor working conditions in this sector, a continuous rural exodus began in the 1960s [49]. This situation was aggravated by the crisis of traditional agriculture in the 1970s, which deepened the continuous emigration that took place in the municipality. This migratory dynamic has continued to the present day, albeit with lower total values that have not broken the continuity of the population drain, due to a rapidly ageing population and low birth rates, which place the municipality, at present, at the lowest total population value in recorded history with a $10 \%$ population loss in the last decade (2011-2020).

\subsection{The Creation of the Agroecological Project Experience on Colective Lands (Extiercol)}

In the context analysed, the intention to initiate a project within agroecology was born within the youth association 'El Peñoncillo' of Cuevas del Becerro. El Peñoncillo is an association with a long tradition in the municipality since it was founded in the 1970s, in which young people from the village participate and carry out different activities throughout the year. In September 2012, the decision to carry out this project was taken in their assemblies where through this participation method weeklythe members of the association met to decide what type actions to develop. Using this method of participation a total of 14 members participated. The starting point was an initial diagnosis carried out at the meetings by the members of the association and in consensus of all members. Then in the assembly each member took the floor to express their evaluation, point of view and opinion on a subject or problem that is likely to change [50] in this case conventional agriculture and the possibility of starting an agro-ecological project. Finally, a working group was created where several members developed the idea of the project and made up the different sections to be formed. This group was formed by the voluntary subscription of interested members of the association, a total of 5 members formed the working group.

From the beginning of the Extiercol project, an associative culture was present and transmitted from 'El Peñoncillo' to Extiercol, involving the members of the association in the start-up of the project and transferring the collective responsibility and management of 
the resources, promoting participative, horizontal and collaborative processes as opposed to conventional models where individualistic, hierarchical and competitive dynamics are predominant. For this purpose, in Extiercol project weekly meetings were held where the work of the previous week was evaluated for the project members, and the work of the following week was planned. In these meetings the planned work was distributed among the members of the project so that each member was responsible for a task and then explained the evolution of the work in the weekly meeting.

With regard to the methods for the information gathering in this study a participatory action research methodology was applied [51] where the authors were an active part of the process together with project members from the beginning to the current day participating in the different processes, in decision-making and in the concrete actions to be developed during research. Using the principles of a participatory action research the data collection and analysis was carried out using a situational analysis tool, conducted face-to-face with project members, which involved the systematic collection of detailed information on everything related to the project from the workplace, procedures and strategies to production, planning and sales.

\section{Results and Discussion}

\subsection{Phase I: Project Initiation}

As a first stage in 2012 (Figure 3), the members of this association decided to collectively carry out a project within the Youth in Action programme established by the European Parliament and of the Council for the period 2007-2013 [52].

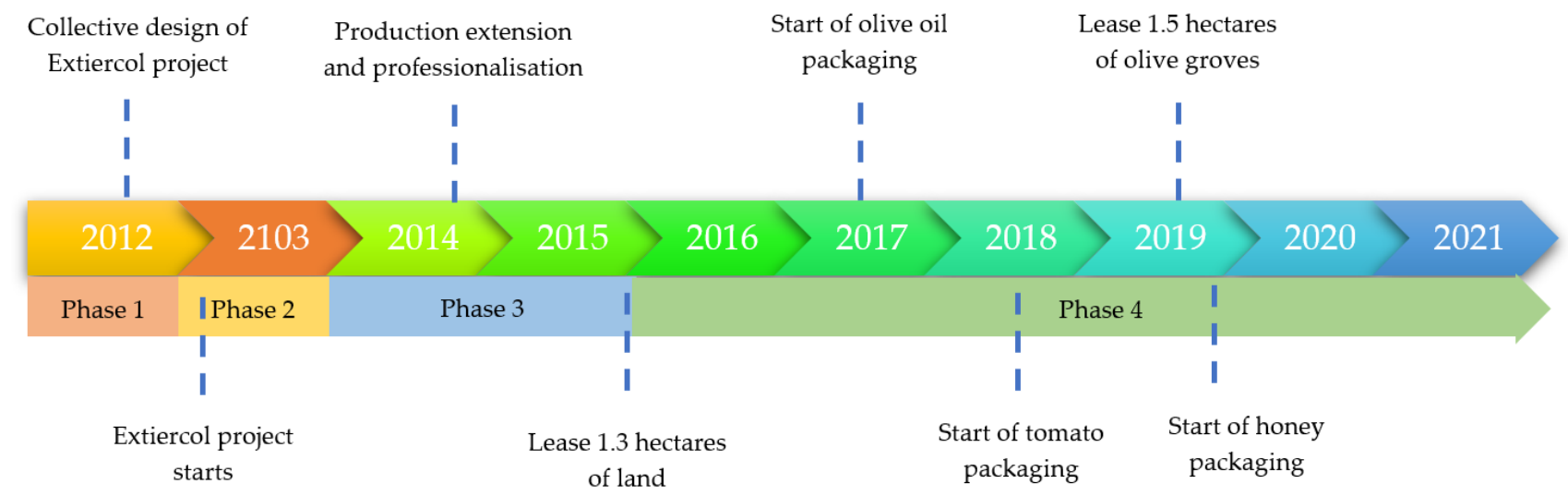

Figure 3. Historical steps in Extiercol project.

Youth in Action was a European programme for all young people aged 15-28 that included a wide variety of actions aimed at youth organisations and collectives. It funded different types of projects, cultural events, sports and non-formal educational activities, in addition to promoting the active participation of young people in society. In this programme, different projects were presented across the European Union, and after a selection process, the projects with the highest scores were funded.

Under the conditions of the Youth in Action programme, the members of the 'El Peñoncillo' youth association elaborated the Extiercol project. The design of Extiercol project consisted of one year of training in theoretical and mainly practical aspects of agro-ecological activity. The practical part covered the whole cycle of multiple vegetable production (tomato, potatoes, peppers, aubergines ... ), covering all possible aspects from the most essential, such as collecting seeds, to the more complex, such as composting and processing vegetables.

The practical work was combined with theoretical and practical training mainly related to the production of compost. The staff of specialists who conducted the training of the Extiercol project was composed by professionals with long experience in implementing, 
developing and advising agroecological projects. Field visits to farms in the province of Málaga under sustainable management were also scheduled. An interesting activity for the Extiercol project members because it responds to their needs in the implementation of sustainable practices and helps them to learn.

In this initial phase, the objectives of the Extiercol project were of a training character with the subsequent possibility of generating employment. The aim was to train young people in agro-ecological techniques, which would allow the reformulation of a sector with historical importance in the economic and social evolution of the municipality. In January 2013, after going through the different administrative phases, the project was approved by the European Commission and funded with 5000 Euros.

\subsection{Phase II: Agroecological Process Begins: Training and Tool Access}

After the Extiercol project was approved, a period was opened for the articulation of a group of young people who would take the project forward; through open assemblies, the project, its strategies and its objectives were explained to all the young people of the village. The aim was to open up the project to the young people of the village, to integrate them and not to close it exclusively to the members of the association. In these spaces for participation, the group of young people who would develop the project was increased to 13 participants all of them without experience in agroecological activity, and the project was started. The economic crisis, which further increased the unemployment levels in the municipality (27.1\% in 2011), favoured the interest of young people in Extiercol project.

With regard to the physical areas for the farm work (Figure 4), the project initially had $500 \mathrm{~m}^{2}$ of self-consumption gardens in the village, as well as a disused and deteriorated municipally owned greenhouse which was added later and which the project members adapted and transformed for agro-ecological activity. In Andalusia, access to resources such as agricultural land and capital has been identified as the main barrier to initiation in the farming sector, especially by young people who do not come from a family tradition linked to agricultural activities [53]. This represents a great difficulty for generational renewal in a highly ageing sector in Europe where, in 2016, for every farm manager under 40, there were three farm managers over 65 [54]. In parallel to this, paradoxically, a long process of land abandonment is taking place in Europe, which has important environmental, socioeconomic and landscape consequences [55-57]. The absence of generational renewal in the agricultural sector could aggravate this trend in the following years, especially in arid, semi-arid and mountain rural areas [58].

The project implementation process began with an intensive training process within agroecology, with the organisation by the members of numerous courses, for which experts in these alternative methods were used, dealing with all the aspects involved in agroecological activity, highlighting the learning of the production of bio-inputs, using local resources, which were intended to be applied as an input in agricultural production.

Through these methods and techniques, which were totally respectful with local resources, the aim was to put the farmer in the middle of the decisions he makes on his farm, breaking the dependence on inputs from industry. Therefore, the project initially focused on learning how to produce their own bio-inputs (compost, mineral broths) with local resources, which would allow them to achieve profitable and stable vegetable production. To produce compost, ingredients from local farms were used, mainly sheep and horse manure with abundant straw and mixed with wood ash and tree leaves collected in the village. 


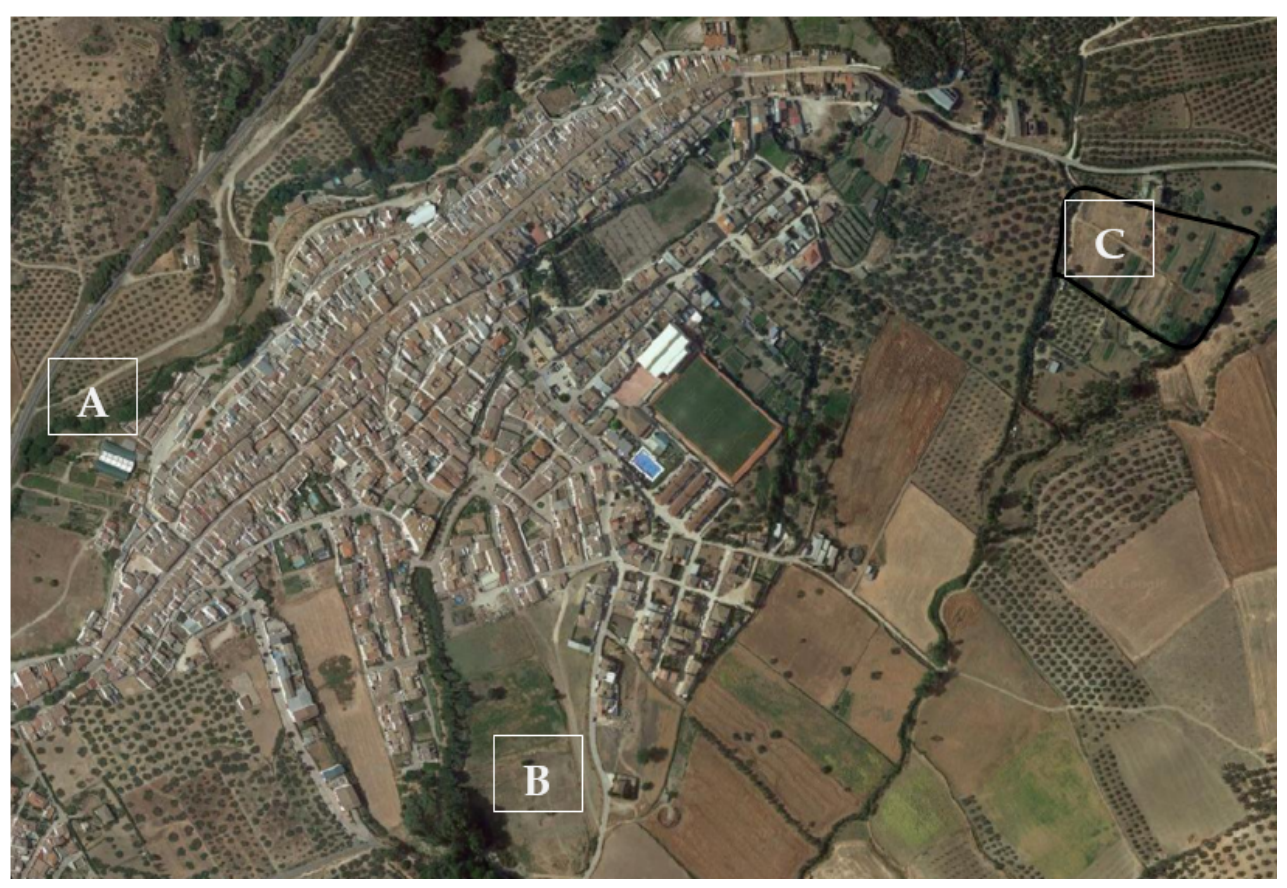

Figure 4. Aerial view of Extiercol project sites at Cuevas del Becerro (Málaga, Spain). (A) Greenhouse (B) Self Cosumption gardens (C) Current farmland.

The results of this phase showed the importance of training in agroecological management techniques and access to resources, especially land, as key factors for the initiation of this agroecological experience, as these initial elements can be decisive for the implementation of an agroecological project. In this sense, the development of sufficiently relevant strategies to promote these two key factors is currently lacking.

\subsection{Phase III: Production and Comercializatoin}

From 2014 onword, a crucial point in this experience took place, outside the funding programme, the members decided to progress from agroecological learning to professionalising the agricutural activity. In this process, some of the initial members of the project decided not to continue, leaving the total number of participants at six. An aspect that should be highlighted is the management of the collective project, which is a conflictive aspect in continuous transformation due to the different positions that can appear within a heterogeneous group of people. Working collectively and taking decisions in assembleis, aspects that were incorporated into this initiative seem fundamental, such as (i) a progressive professionalisation of the work, (ii) the construction of common rules that meet the needs of the members and the initiative and (iii) the creation of work spaces within the initiative, where each person identifies in a specific way with the task to be carried out.

At this point, good working dynamics were created and the cultivation space was kept under control, establishing weekly work tasks among the members of the project and keeping track of these activities in the meetings that took place within the project, moving towards professionalisation. A key factor in the progress from the learning phase to the professionalisation phase in Extiercol was the leasing of 1.3 hectares of farmland. This land was managed under the conventional system for rain-fed cereal cultivation, and the Extiercol project members transformed it into an agro-ecological space for multiple vegetable cultivation. The adaptation of the farmland to agro-ecological management required a significant effort not only in terms of economic resources but also in terms of personnel work, due to the spontaneous vegetation removal, the installation of the irrigation system and the application of compost to the farm. In this phase, the inflow of capital from the sale of horticultural products was largely used for reinvestment, determining the progress of the project since the cultivated land increase involved the sprinkler irrigation system instal- 
lation from the system of irrigation ditches that runs through the vegetable gardens around the village and the purchase of agricultural machinery, a small tractor and equipment for working in the fields. Management change from conventional to agroecological farming systems involves a transition process [59] as a result of which farms are transformed into resilient and sustainable agroecosystems under sustainable agricultural practices implying crop diversification and low external inputs, and a reconnection between the farming system and its ecological and social environment. The efforts of the Extiercol project members were dedicated to a farmland that is not their property (five- year lease) with the insecurity that this implies, because at the end of the contract they could lose the farm, especially in a process of transition towards an agro-ecological model that requires the restoration and improvement of the quality of degraded soils.

These typologies of small farms are generally more productive and contain a greater diversity of crops and biodiversity than large farms, making them more resilient [60]. However, small farms have not been favoured by agricultural policies; in these sense, the proposal for the new CAP, which will be in force between 2023 and 2027, still favours larger farms because the bulk of payments are distributed on the basis of land area [61].

This farm lease increased the project's scale, with more than 40 varieties of horticultural crops grown throughout the year, and many of these varieties are local seeds. These seeds have been recovered from the surrounding areas, many of them from the seed bank of the Serranía de Ronda, this seed bank belongs to the Silvema Association, a non-profit organisation that has been working since 1988 for the protection of the environment, and others directly from farmers who maintain local varieties. Behind the use of these seeds was not only independence from the seed industry and the idea of the farmer as a central agent in decisions regarding his land, but there was also a differentiation from the conventional market through these native seeds which, on many occasions, are not interesting for the agri-food system for reasons that are far from the interests of consumers and are centred on logistical and economic issues of large supermarkets and distributors. On the other hand, local varieties of seeds have been demonstrated to be more resistant and adaptable to the impacts of climate change [62].

In agroecological processes, direct, clear and flexible marketing chains are essential, where trust and recognition of those involved play a decisive role [39]. In this case, the generation process of these alliances was gradual, first in circles of friends and acquaintances and then extending to other people who were reached through word of mouth or the many meetings, workshops, seminars etc. in which the Extiercol members participated. As a result of participating in these events, groups of people committed to the project were created who consume the food produced by the project on a regular basis, this being the main marketing chain for the garden's products. Currently, a network of 50 families supports the project, mainly in Ronda and Málaga and is working on a partnership between the project and consumers to create a formal organisation. The disconnection between production processes and consumers has been identified as one of the factors leading to unsustainable food consumption, especially in highly urbanised areas [63]. Under this consumption model, the connection to the production processes and farm sustainability is promoted, thus establishing interactions between rural and urban areas. Participation in these consumer groups can increase social identity and awareness of the impact of collective actions. These aspects are pointed out as determinants in increasing environmental awareness and thus the approach to environmental and sustainable processes [64].

Small shops, generally specialised, are an important ally, both as a point of contact with consumers and as a space for selling garden produce. Weaving these alliances is an essential aspect, as we find ourselves agents who, within the agri-food system, suffer the consequences of an unequal power correlation. In addition the process of direct farmer to consumer marketing outside of conventional sales channels is fundamental because with direct sales, the profitability of production is higher due to the increase in the profit margin of the product as a result of the elimination of intermediaries in the food chain. 
The crop diversification on the farmland determines the marketing system, which involves two modalities, the box model with 6-7 vegetable varieties and the grouping of consumers with the possibility of choosing variety and quantity. This second modality is subject to the first, which the members understand to be more loyal and committed. With three weekly delivery routes, one local, one to Ronda and one to Malaga, for groups of consumers and shops, rural-urban alliances are essential to sustain an agro-ecosystem that is consistent with its philosophy and healthy, conscious and responsible food. In this sense, several studies have demonstrated the environmental and climatic benefits of diversified farming, as well as seasonally and proximally produced food products [65-67].

In this phase, the relationship between Extiercol project and the consumers, the approximation between the production and consumption phases have been shown to be essential in the development of the agro-ecological project, being important the construction of spaces for the meeting of both spheres. In these agro-ecological systems of production, distribution and consumption, new alliances between farmers and consumers seem fundamental as an alternative proposal to organise the current agro-food system and towards a new rural-urban relationship reconnected with nature. Consumer adaptation to this production and marketing model is part of the agroecological strategy where the consumer is aware of the process and maintains close contact with the production processes and the advantages that derive from them. In this sense, the trust relationship between Extiercol and the consumers has allowed the project to be supported from the beginning, without the need to obtain official accreditation as agroecological land. For this reason, this model is often restricted to consumers with a high level of environmental awareness; nevertheless, it achieves a strong connection between producers and consumers [68].

\subsection{Phase IV: Value Chain Increase}

Since 2017, Extiercol has been committed to the processing of primary products as a strategy to add new products that open up new marketing chains, complementing the current ones and increasing the profitability of its productions. The objective was to have a diverse offering of products, initially with small productions that allow not only diversification of the agricultural activity but also expansion of the commercial capacity by offering consumers a greater number of products.

The first step in this process of processing primary products was taken with olive oil production. Since the 2016/2017 campaign, where the first tests were carried out, there has been a continuous increase in the production and marketing of this product, which has led to an increase from 538 litres of oil in the 2016/2017 campaign to 1556 litres in the 2020/21 campaign (Figure 5). The incorporation of new farmers from the area who, coming from industrial agriculture, changed their olive grove management model to market their production together with that of Extiercol, as well as the increase in the project's olive grove land with the leasing of 1.5 ha in 2019 , was fundamental in this process of production increase. In this sense, the incorporation of new farmers into the experience and the replication of agroecological management on their farms was, without a doubt, a really positive aspect towards the sustainability of local agricultural management. 


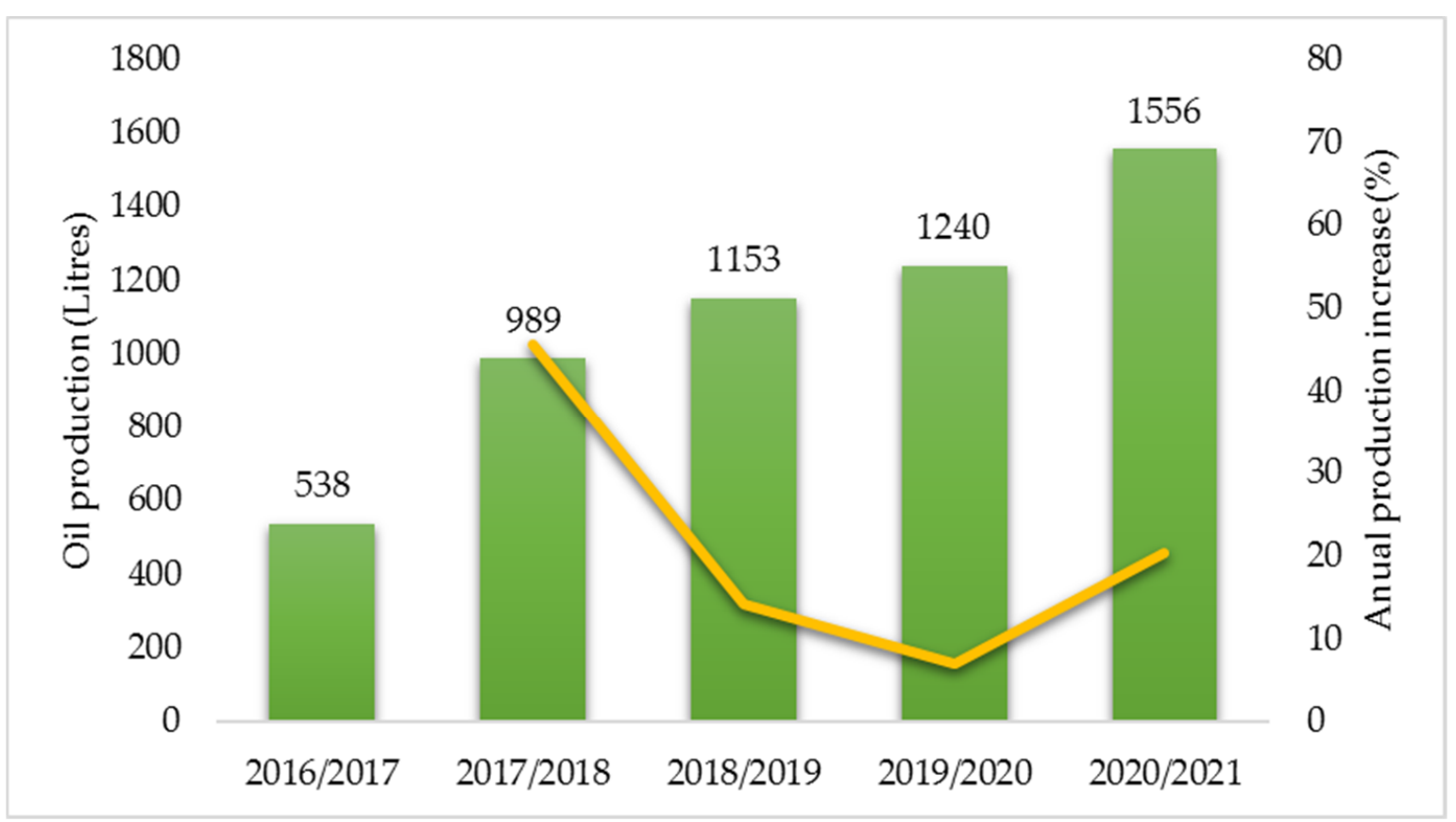

Figure 5. Annual olive oil production in Extiercol project. Green bars represent total production (Litres) and yellow line annual increase $(\%)$.

An added element in the processing process was the accompanying of the oil bottles with a label indicating the individual costs of the production steps for each bottle: processing process, workers' salaries, reinvestment in the Extiercol project or land leasing. This value label brought the consumer closer to the project, showed its influence and capacity to reverse the current ways with its consumption. In Spain, the reasons for which the consumer buys organic olive oil are usually related to health, food safety and taste [69]. However, environmental preservation does not appear among the current consumer priorities. Due to the economic and territorial importance of olive groves in Spain and especially in Andalusia, it seems necessary to place a greater emphasis on the environmental qualities that olive groves under organic management can offer. In this sense several studies have shown how organic olive groves management in Andalusia improves the capacity to provide ecosystem services [70-73]. Since the 2018/2019 campaign, the Extiercol project has incorporated among its products the tomato jars packaged under the brand 'Tomate Rosado' (Figure 6), with which the project team have had positive experiences. This is a local variety of tomato (Pink Tomato); with this process, as well as extending the range of products on offer and generating added value, it also provides an outlet for possible summer surpluses as well as incorporating the product in the winter months when the tomato plant in open air conditions in the climatic conditions where the study area is located does not produce, so consumers cannot obtain this product. In 2020, 550 jars of tomatoes were packaged. Both the processing of olive oil and tomato jars are carried out in small processing plants close to the municipality where the products are processed under organic and sanitary standards. 

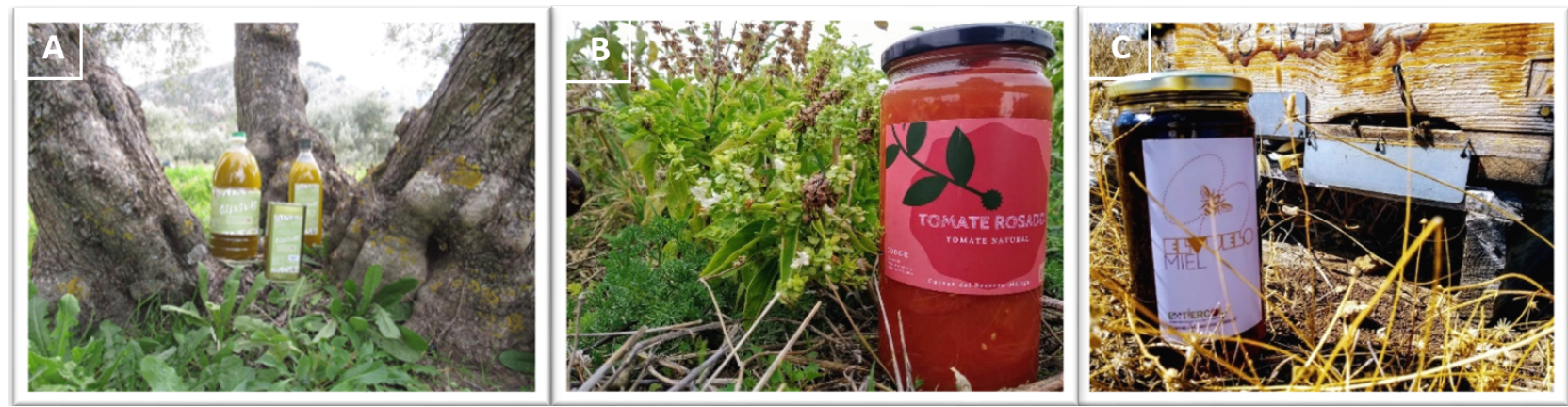

Figure 6. Products packaged in Extiercol project: (A) Olive oil, (B) Tomato jars, (C) Honey.

In order to expand the range of products in the consumer network, honey has been added to the consumer offering since 2019. As in olive oil production, other beekeepers were involved in the production of honey, as the number of own hives in the project is not very large. At present, $520 \mathrm{~kg}$ of honey is marketed annually, and the intention is to continue increasing this product, as well as oil and tomato packaging.

In this phase, the multifunctionality and diversification of the agro-ecological project has been highlighted. The relationship with other farmers and agents in the food chain, in this case in the processing sector, has been fundamental. These relationships not only favour an increase in the scale of the project but also improve efficiency, as in the case of tomatoes, where there was a reduction in harvest losses. In these sense, future challenges for the project include the involvement of a greater number of farmers to bring about a significant change in local production methods and the extension of processing to a wider range of horticultural products.

\subsection{The Extiercol Project as a Model Case}

The process and methodology developed can be extrapolated to any other place, although fundamental aspects such as 1. an analysis that identifies local opportunities, problems and needs, as well as the assessment of traditional knowledge 2. participatory and collaborative work that aims to include the concerns and aspirations of the participants so that they feel that the initiative is their own and 3. a training process that allow them to learn sustainable production methods are important.

In the replicability of this agroecological model and its extension to a larger scale a possible risk is its possible conventionalisation, i.e., the exclusive adoption of certain aspects that comply with the organic regulations but not substantially modify the structures and methods of conventional agriculture $[74,75]$ that have resulted in the current critical situation of the agricultural sector. For example, the monoculture crops are allowed under organic regulations, which barely contribute to the agroecosystem's sustainability [76]. It conventionalisation also implies the integration of the organic sector in conventional processing and marketing structures in which the production, distribution and consumption of organic food implies the processing of organic food into homogenous mass-produced commodities, controlled by audited certification and distributed through the mass food chain dominated by large companies far removed from the farmers and rural areas [77].

Similarly, in line with [78] by simply replacing the synthetic inputs with organic ones on the farm, the methods and actions of conventional agriculture are not questioned, with the intention that a given input or technique should replace another that was practised in conventional agriculture, and, furthermore, that the same results should be obtained as before. Thus, in the reconversion of production areas, there is no reconversion in the forms of action, nor is there a questioning of previous methods, this process has been detected in Andalusia region [79]. In short, the aim is to replace inputs individually, when there should be a change in the relationships and ways of acting as a whole, which implies a holistic vision of the agro-ecosystem, since, if this is not the case, there is no complete and 
diverse ecological action, and we will be exposed to the risks posed by the imbalances in these types of production.

Throughout the process of this experience, there has been an evolution, a transformation in the perception of the activity or at least of the components that have developed this project with these agro-ecological methods, which has taken the members of the project from 'ignorant to experts'. This means that they are transferring knowledge and other farmers are taking on board the management and operating methods that the project has set out since its beginnings, with more farmers appearing who are discordant with conventional methods. In this sense, the implementation of sustainable management including vegetation cover has been negatively perceived by farmers in some areas [80], and this perception could be an obstacle to the inclusion of these management systems. In this case study, the inclusion of farmers' crops could be the beginning of a transition towards sustainable models on a larger scale in the analysed area.

In the success of this project, several aspects can be highlighted; among them is the quality of the products. This is due to their proximity, which allows us to maintain their freshness and harvest them in an optimal state of maturity, enhancing the flavour with which they reach the consumer. Consumers are attracted to organic food because it is produced without synthetic chemicals, and there is a growing interest in healthy consumption patterns. However, in a significant transformation of production systems towards more sustainable systems, a high degree of consumer awareness is essential to demand a real change in the methods applied in conventional agriculture. On the other hand, the implementation of public policies that encourage the regionalisation of production and local consumption could be an interesting way to reduce our carbon footprint and emissions and to maintain populations in rural areas while promoting food security.

\section{Conclusions}

The challenge for agriculture posed by the changes arising from the climate change process or the loss of biodiversity has led to a growing interest in undertaking actions to promote sustainable agroecosystem models with a new emphasis on agroecology. Small diversified farms under sustainable management practices such as those analysed by this study may be typologies that can play an important role in the mitigation of the effects derived from the climate change process, and thus further attention seems necessary.

Throughout this work, we have shown an agroecological experience in the rural area that, taking into account its multifunctional character, has developed an agroecological project to enhance its functions, such as the provision of healthy and quality products, the maintenance of the population and sustainable local production systems that aim to restructure agri-food production. On the other hand, this process has shown how the closer relations between food production area and nearby urban areas have been fundamental in connecting both territories and the people who inhabit them and thus connect society with the sustainable use of agroecosystems. In this study elaborates on important criteria for the agroecological project development, detailed practical aspects, addresses problems and discusses the impact of the project in a wider socio-economic setting.

The content of this article could be interest regarding the UN SDGs, the Green Deal, the Horizon Europe Mission on Soil Health and Food, and the recent activities of the SCAR strategic working group on Agroecology. In this regard, we think that our practical aspects and experience as described in the article could be high value to the research community.

Author Contributions: Conceptualization, B.L.-G. and M.G.-R.; methodology, B.L.-G., L.P.-A., J.A.-H. and M.G.-R.; validation, B.L.-G., L.P.-A. and M.G.-R.; formal analysis, B.L.-G. and L.P.-A.; investigation, L.P.-A., B.L.-G., J.A.-H. and M.G.-R.; resources, B.L.-G. and M.G.-R.; data curation, M.G.-R.; writing-original draft preparation, M.G.-R.; writing-review and editing, M.G.-R., B.L.-G. and L.P.-A.; visualization, B.L.-G., M.G.-R. and L.P.-A.; supervision, B.L.-G., M.G.-R. and L.P.-A. All authors have read and agreed to the published version of the manuscript. 
Funding: This research received no external funding.

Institutional Review Board Statement: Not applicable.

Data Availability Statement: Data sharing not applicable.

Acknowledgments: We are grateful to the members of Extiercol project (Cristobal, José, Pedro, Heredia and Juan Ramón) for their collaboration in the realization of this research.

Conflicts of Interest: The authors declare no conflict of interest.

\section{References}

1. Informe Anual de Indicadores. Agricultura, Pesca y Alimentación. 2019. Available online: https://www.mapa.gob.es/es/ ministerio/servicios/analisis-y-prospectiva/indicadores_semestre.aspx (accessed on 25 May 2021).

2. Aguilera, E.; Guzmán, G.I.; de Molina, M.G.; Soto, D.; Infante-Amate, J. From animals to machines. The impact of mechanization on the carbon footprint of traction in Spanish agriculture: 1900-2014. J. Clean. Prod. 2019, 221, 295-305. [CrossRef]

3. Medina, L.J.G.; Rodrigo, E.C. La ocupación en el sector agrario: Trayectoria y actualidad. Panor. Soc. 2020, 31, 113-124.

4. Taylor, P.J.; Flint, C. Geografía Política: Economía-Mundo, Estado-Nación y Localidad, 2nd ed.; Trama: Madrid, Spain, $2002 ;$ p. 447.

5. Camilleri, A.R.; Larrick, R.P.; Hossain, S.; Patino-Echeverri, D. Consumers underestimate the emissions associated with food but are aided by labels. Nat. Clim. Chang. 2019, 9, 53-58. [CrossRef]

6. European Commission. Employment and Social Developments in Europe: 2019 Review; European Commission: Luxembourg, 2019; Available online: https:/ / ec.europa.eu (accessed on 10 May 2021).

7. Alons, G. Environmental Policy Integration in the EU's Common Agricultural Policy: Greening or Greenwashing? J. Eur. Public Policy 2017, 24, 1604-1622. [CrossRef]

8. Gocht, A.; Ciaian, P.; Bielza, M.; Terres, J.M.; Röder, N.; Himics, M.; Salputra, G. EU-Wide Economic and Environmental Impacts of CAP Greening with High Spatial and Farm-Type Detail. J. Agric. Econ. 2017, 68, 651-681. [CrossRef]

9. Hristov, J.; Clough, Y.; Sahlin, U.; Smith, H.G.; Stjernman, M.; Olsson, O.; Brady, M.V. Impacts of the EU's Common Agricultural Policy "Greening" Reform on Agricultural Development, Biodiversity, and Ecosystem Services. Appl. Econ. Perspect. Policy 2020, 42, 716-738. [CrossRef]

10. European Union. From Farm to Fork Strategy: For a Fair, Healthy and Environmentally-Friendly Food System; European Commission: Brussels, Belgium, 2020.

11. Piorr, A.; Zasada, I.; Doernberg, A.; Zoll, F.; Ramme, W. Research for AGRI Committee-Urban and Peri-Urban Agriculture in the EU; European Parliament: Brussels, Belgium, 2018.

12. Caporali, F. History and development of agroecology and theory of agroecosystems. In Law and Agroecology; Springer: Berlin/Heidelberg, Germany, 2015; pp. 3-29.

13. IPCC. Special Report on Global Warming of 1.5. Available online: https:/ / www.ipcc.ch/sr15/ (accessed on 20 May 2021).

14. Dai, T.; Yang, Y.; Lee, R.; Fleischer, A.S.; Wemhoff, A.P. Life cycle environmental impacts of food away from home and mitigation strategies-A review. J. Environ. Manag. 2020, 265, 110471. [CrossRef]

15. Sullivan, G.T.; Ozman-Sullivan, S.K. Alarming evidence of widespread mite extinctions in the shadows of plant, insect and vertebrate extinctions. Austr. Ecol. 2021, 46, 163-176. [CrossRef]

16. Singh, J.; Schädler, M.; Demetrio, W.; Brown, G.G.; Eisenhauer, N. Climate change effects on earthworms-A review. SOIL Org. 2019, 91, 114-138. [CrossRef]

17. Ghosh, A.; Misra, S.; Bhattacharyya, R.; Sarkar, A.; Singh, A.K.; Tyagi, V.C.; Kumar, R.V.; Meena, V.S. Agriculture, dairy and fishery farming practices and greenhouse gas emission footprint: A strategic appraisal for mitigation. Environ. Sci. Pollut. Res. 2020, 27, 10160-10184. [CrossRef]

18. González-Rosado, M.; Parras-Alcántara, L.; Aguilera-Huertas, J.; Lozano-García, B. Long-term evaluation of the initiative 4\%o under different soil managements in Mediterranean olive groves. Sci. Total. Environ. 2021, 758, 143591. [CrossRef]

19. Hendrickson, M.K.; Heffernan, W.D. Opening spaces through relocalization: Locating potential resistance in the weaknesses of the global food system. Sociol. Rural. 2002, 42, 347-369. [CrossRef]

20. Inventario Nacional de Gases de Efecto Invernadero (GEI). 2019. Available online: https:/ /www.miteco.gob.es/es/calidad-yevaluacion-ambiental/temas/sistema-espanol-de-inventario-sei-/es-2021-nir_tcm30-523942.pdf (accessed on 2 May 2021).

21. Sanz-Cobena, A.; Lassaletta, L.; Aguilera, E.; del Prado, A.; Garnier, J.; Billen, G.; Smith, P. Strategies for greenhouse gas emissions mitigation in Mediterranean agriculture: A review. Agric. Ecosyst. Environ. 2017, 238, 5-24. [CrossRef]

22. Paustian, K.; Lehmann, J.; Ogle, S.; Reay, D.; Robertson, G.P.; Smith, P. Climate-smart soils. Nature 2016, 532, 49-57. [CrossRef]

23. Oldfield, E.E.; Wood, S.A.; Bradford, M.A. Direct effects of soil organic matter on productivity mirror those observed with organic amendments. Plant Soil 2018, 423, 363-373. [CrossRef]

24. González-Rosado, M.; Parras-Alcántara, L.; Aguilera-Huertas, J.; Lozano-García, B. Soil Productivity Degradation in a Long-Term Eroded Olive Orchard under Semiarid Mediterranean Conditions. Agronomy 2021, 11, 812. [CrossRef]

25. González-Rosado, M.; Lozano-García, B.; Aguilera-Huertas, J.; Parras-Alcántara, L. Short-term effects of land management change linked to cover crop on soil organic carbon in Mediterranean olive grove hillsides. Sci. Total Environ. 2020, 744, 140683. [CrossRef] 
26. Bogunovic, I.; Telak, L.J.; Pereira, P. Agriculture management impacts on soil properties and hydrological response in Istria (Croatia). Agronomy 2020, 10, 282. [CrossRef]

27. Morugán-Coronado, A.; Linares, C.; Gómez-López, M.D.; Faz, A.; Zornoza, R. The impact of intercropping, tillage and fertilizer type on soil and crop yield in fruit orchards under Mediterranean conditions: A meta-analysis of field studies. Agric. Syst. 2020, 178, 102736. [CrossRef]

28. Zomer, R.J.; Bossio, D.A.; Sommer, R.; Verchot, L.V. Global sequestration potential of increased organic carbon in cropland soils. Sci. Rep. 2017, 7, 1-8. [CrossRef]

29. Bombino, G.; Denisi, P.; Gómez, J.A.; Zema, D.A. Mulching as best management practice to reduce surface runoff and erosion in steep clayey olive groves. Int. Soil Water Conserv. Res. 2020, 9, 26-36. [CrossRef]

30. Wiesmeier, M.; Mayer, S.; Paul, C.; Helming, K.; Don, A.; Franko, U.; Steffens, M.; Kögel-Knabner, I. $\mathrm{CO}_{2}$ certificates for carbon sequestration in soils: Methods, management practices and limitations. BonaRes Ser. 2020, 4, 1-23. [CrossRef]

31. Veerman, C.; Pinto Correia, T.; Bastioli, C.; Biro, B.; Bouma, J.; Cienciela, E. Caring for soil is caring for life. In EU Soil Health and Food Mission Board; European Commission: Brussels, Belgium, 2020.

32. Puigdueta, I.; Aguilera, E.; Cruz, J.L.; Iglesias, A.; Sanz-Cobena, A. Urban agriculture may change food consumption towards low carbon diets. Glob. Food Secur. 2021, 28, 100507. [CrossRef]

33. Pichler, P.P.; Zwickel, T.; Chavez, A.; Kretschmer, T.; Seddon, J.; Weisz, H. Reducing urban greenhouse gas footprints. Sci. Rep. 2017, 7, 1-11. [CrossRef]

34. Kriewald, S.; Pradhan, P.; Costa, L.; Ros, A.G.C.; Kropp, J.P. Hungry cities: How local food self-sufficiency relates to climate change, diets, and urbanisation. Environ. Res. Lett. 2019, 14, 094007. [CrossRef]

35. Vicente-Vicente, J.L.; Piorr, A. Can a shift to regional and organic diets reduce greenhouse gas emissions from the food system? A case study from Qatar. Carbon Balance Manag. 2021, 16, 2. [CrossRef]

36. C40 Food Systems Network. 2019. Available online: www.c40.org/networks/food_systems (accessed on 5 June 2021).

37. Fabbri, K. Food 2030: Future-proofing our food systems through research and innovation. Brussels 2017, 1, 4-44. [CrossRef]

38. Van der Ploeg, J.D. The political economy of agroecology. J. Peasant. Stud. 2021, 48, 274-297. [CrossRef]

39. Anderson, C.R.; Bruil, J.; Chappell, M.J.; Kiss, C.; Pimbert, M.P. From Transition to Domains of Transformation: Getting to Sustainable and Just Food Systems through Agroecology. Sustainability 2019, 11, 5272. [CrossRef]

40. Altieri, M.A.; Nicholls, C.I. Agroecology and the reconstruction of a post-COVID-19 agriculture. J. Peasant. Stud. 2020, 47, 881-898. [CrossRef]

41. Vaarst, M.; Escudero, A.G.; Chappell, M.J.; Brinkley, C.; Nijbroek, R.; Arraes, N.A.M.; Andreasen, L.; Gattinger, A.; De Almeida, G.F.; Bossio, D. Exploring the concept of agroecological food systems in a city-region context. Agroecol. Sustain. Food Syst. 2018, 42, 686-711. [CrossRef]

42. De Bernardi, P.; Azucar, D. The Food System Grand Challenge: A Climate Smart and Sustainable Food System for a Healthy Europe. In Innovation in Food Ecosystems; Springer: Cham, Switzerland, 2020; pp. 1-25. [CrossRef]

43. Bouma, J. Soil security as a roadmap focusing soil contributions on sustainable development agendas. Soil Secur. $2020,1,100001$. [CrossRef]

44. Isgren, E.; Ness, B. Agroecology to Promote Just Sustainability Transitions: Analysis of a Civil Society Network in the Rwenzori Region, Western Uganda. Sustainability 2017, 9, 1357. [CrossRef]

45. Altieri, M.A. Agroecology: A new research and development paradigm for world agriculture. Agric. Ecosyst. Environ. 1989, 27, 37-46. [CrossRef]

46. Gliessman, S.R. Agroecology: The Ecology of Sustainable Food Systems; CRC Press: Boca Raton, FL, USA, 2014.

47. Altieri, M.A. Agroecology: The Science of Sustainable Agriculture; CRC Press: Boca Raton, FL, USA, 2018.

48. Del Valle Ramos, C.; Almoguera, P. Envejecimiento demográfico y (des) población en las ciudades medias interiores de Andalucía (2008-2018). Cuad. Geográficos De La Univ. De Granada 2020, 59, 263-286. [CrossRef]

49. González-Rosado, M. Desarrollo Local en Zonas Rurales Atrasadas: El Caso de Cuevas del Becerro. Master's Thesis, University of Málaga, Málaga, Spain, 2013.

50. Martínez, M. Ciencia y Arte en la Metodología Cualitativa; Trillas: México, Mexico, 2009.

51. McIntyre, A. Participatory Action Research; Sage Publications: Thousand Oaks, CA, USA, 2007.

52. Decision No 1719/2006/EC of the European Parliament and of the Council of 15 November 2006 Establishing the Youth in Action Programme for the Period 2007 to 2013. Available online: https://eur-lex.europa.eu/eli/dec/2006/1719/oj (accessed on 18 July 2021).

53. Estudio Sobre el Acceso a la Tierra: Documento Final del Grupo Focal de Acceso a la Tierra. Ministerio de Agricultura, Pesca y Alimentación. 2020. Available online: https://cpage.mpr.gob.es/producto/estudio-sobre-el-acceso-a-la-tierra/ (accessed on 12 May 2021).

54. Commission Staff Working Document. Executive Summary of the Evaluation of the Impact of CAP on Generational Renewal. Local Development and Jobs in Rural Areas. Available online: https: / / ec.europa.eu/info/sites/default/files/food-farming-fisheries / key_policies/documents/ext-eval-cap-gene-renewal-study-exe-summary_2021_en.pdf (accessed on 18 May 2021).

55. Lasanta, T.; Nadal-Romero, E.; Arnáez, J. Managing abandoned farmland to control the impact of re-vegetation on the environment. The state of the art in Europe. Environ. Sci. Policy 2015, 52, 99-109. [CrossRef] 
56. Levers, C.; Schneider, M.; Prishchepov, A.V.; Estel, S.; Kuemmerle, T. Spatial variation in determinants of agricultural land abandonment in Europe. Sci. Total. Environ. 2018, 644, 95-111. [CrossRef] [PubMed]

57. Dolton-Thornton, N. How should policy respond to land abandonment in Europe? Land Use Policy 2021, 102, 105269. [CrossRef]

58. Lasanta, T.; Arnáez, J.; Pascual, N.; Ruiz-Flaño, P.; Errea, M.P.; Lana-Renault, N. Space-time process and drivers of land abandonment in Europe. Catena 2017, 149, 810-823. [CrossRef]

59. Gliessman, S.R.; Rosemeyer, M. The Conversion to Sustainable Agriculture: Principles, Processes and Practices; CRC Press: Boca Raton, FL, USA, 2009.

60. Ricciardi, V.; Mehrabi, Z.; Wittman, H.; James, D.; Ramankutty, N. Higher yields and more biodiversity on smaller farms. Nat. Sustain. 2021, 4, 651-657. [CrossRef]

61. Pe'er, G.; Bonn, A.; Bruelheide, H.; Dieker, P.; Eisenhauer, N.; Feindt, P.H.; Lakner, S. Action needed for the EU Common Agricultural Policy to address sustainability challenges. People Nat. 2020, 2, 305-316. [CrossRef]

62. Westengen, O.T.; Brysting, A.K. Crop adaptation to climate change in the semi-arid zone in Tanzania: The role of genetic resources and seed systems. Agric. Food Secur. 2014, 3, 3. [CrossRef]

63. Goldstein, B.; Birkved, M.; Fernández, J.; Hauschild, M. Surveying the environmental footprint of urban food consumption. J. Ind. Ecol. 2016, 21, 151-165. [CrossRef]

64. Bamberg, S.; Rees, J.; Seebauer, S. Collective climate action: Determinants of participation intention in community-based pro-environmental initiatives. J. Environ. Psychol. 2015, 43, 155-165. [CrossRef]

65. Tobarra, M.A.; Lopez, L.A.; Cadarso, M.A.; Gomez, N.; Cazcarro, I. Is seasonal households' consumption good for the nexus carbon/water footprint? The Spanish fruits and vegetables case. Environ. Sci. Technol. 2018, 52, 12066-12077. [CrossRef]

66. Ivanova, D.; Barrett, J.; Wiedenhofer, D.; Macura, B.; Callaghan, M.; Creutzig, F. Quantifying the potential for climate change mitigation of consumption options. Environ. Res. Lett. 2020, 15, 093001. [CrossRef]

67. Pradhan, P.; Kriewald, S.; Costa, L.; Rybski, D.; Benton, T.G.; Fischer, G.; Kropp, J.P. Urban food systems: How regionalization can contribute to climate change mitigation. Environ. Sci. Technol. 2020, 54, 10551-10560. [CrossRef]

68. Wezel, A.; Bellon, S.; Doré, T.; Francis, C.; Vallod, D.; David, C. Agroecology as a science, a movement and a practice. A Review. Agron. Sustain. Dev. 2009, 29, 503-515. [CrossRef]

69. Vega-Zamora, M.; Parras, R.M.; Murgado, A.E.M.; Torres, R.F.J. The influence of the term organic on food purchasing behaviour. Procedia Soc. Behav. Sci. 2013, 81, 660-671. [CrossRef]

70. Parras-Alcántara, L.; Díaz, J.L.; Lozano-García, B. Organic farming affects C and N in soils under olive groves in Mediterranean areas. Land Degrad Dev. 2013, 26, 800-806. [CrossRef]

71. Parras-Alcántara, L.; Lozano-García, B. Conventional tillage vs. organic farming in relation to soil organic carbon stock in olive groves inMediterranean rangelands (southern Spain). Solid Earth Discuss 2014, 6, 35-70. [CrossRef]

72. Soriano, M.A.; Álvarez, S.; Landa, B.B.; Gómez, J.A. Soil properties in organic olive orchards following different weed management in a rolling landscape of Andalusia, Spain. Renew. Agric. Food Syst. 2013, 29, 83-91. [CrossRef]

73. Pleguezuelo, C.R.R.; Zuazo, V.H.D.; Martínez, J.R.F.; Peinado, F.J.M.; Martín, F.M.; Tejero, I.F.G. Organic olive farming in Andalusia, Spain. A review. Agron. Sustain. Dev. 2018, 38, 1-16. [CrossRef]

74. Best, H. Organic agriculture and the conventionalization hypothesis: A case study from West Germany. Agric. Hum. Values 2008, 25, 95-106. [CrossRef]

75. Darnhofer, I.; Lindenthal, T.; Bartel-Kratochvil, R.; Zollitsch, W. Conventionalisation of organic farming practices: From structural criteria towards an assessment based on organic principles. A review. Agron. Sustain. Dev. 2010, 30, 67-81. [CrossRef]

76. Aguilera, E.; Díaz-Gaona, C.; García-Laureano, R.; Reyes-Palomo, C.; Guzmán, G.I.; Ortolani, L.; Rodríguez-Estévez, V. Agroecology for adaptation to climate change and resource depletion in the Mediterranean region. A review. Agric. Syst. 2020, 181, 102809. [CrossRef]

77. Navarrete, M. How do farming systems cope with marketing channel requirements in organic horticulture? The case of market-gardening in south eastern France. J. Sustain. Agric. 2009, 33, 552-565. [CrossRef]

78. Gliessman, S. Transforming food systems with agroecology. Agroecol. Sustain. Food Syst. 2016, 40, 187-189. [CrossRef]

79. Ramos García, M.; Guzmán, G.I.; González De Molina, M. Dynamics of organic agriculture in Andalusia: Moving toward conventionalization? Agroecol. Sustain. Food Syst. 2018, 42, 328-359. [CrossRef]

80. Cerdà, A.; Rodrigo-Comino, J.; Giménez-Morera, A.; Keesstra, S.D. Hydrological and erosional impact and farmer's perception on catch crops and weeds in citrus organic farming in Canyoles river watershed, Eastern Spain. Agric. Ecosyst. Environ. 2018, 258, 49-58. [CrossRef] 